tion of lipoprotein species by paper electrophoresis in albumin-containing buffer. J. Lab. Clin. Med. 61:518-528.

19. Fredrickson, D.S., Levy, R.I., and Lees, R.S. 1967. Fat transport in lipoproteins: An integrated approach to mechanisms and disorders [review]. N. Engl. J. Med. 276:148-156.

20. Fredrickson, D.S. 1993. Phenotyping. On reaching base camp (1950-1975). Circulation. 87(Suppl. 4): III1-III15.

21. Burstein, M., and Samaille, J. 1958. Determination of serum beta-lipoproteins after selective precipitation by heparin. Presse Med. 66:974-975.

22. Friedewald, T., Levy, R.I., and Frederickson, D.S 1972. Estimation of the concentration of lowdensity lipoprotein cholesterol in plasma, without use of the preparative ultracentrifuge. Clin. Chem. 6:499-503.

23. [Anonymous]. 1984. The Lipid Research Clinics Coronary Primary Prevention Trial results. I. Reduction in incidence of coronary heart disease. JAMA. 251:351-364.

24. [Anonymous]. 1984. The Lipid Research Clinics Coronary Primary Prevention Trial results. II. The relationship of reduction in incidence of coronary heart disease to cholesterol lowering.
JAMA. 251:365-374.

25. Hulley, S.B., Rosenman, R.H., Bawol, R.D., and Brand, R.J. 1980. Epidemiology as a guide to clinical decisions. The association between triglyceride and coronary heart disease. N. Engl. J. Med. 302:1383-1389.

26. Austin, M.A., Hokanson, J.E., and Edwards, K.L. 1998. Hypertriglyceridemia as a cardiovascular risk factor. Am. J. Cardiol. 81:7B-12B.

27. Assmann, G., Schulte, H., Funke, H., and von Eckardstein, A. 1998. The emergence of triglycerides as a significant independent risk factor in coronary artery disease. Eur. Heart J. 19(Suppl. M):M8-M14.

28. Frost, P.H., and Havel, R.J. 1998. Rationale for use of non-high-density lipoprotein cholesterol rather than low-density lipoprotein cholesterol as a tool for lipoprotein cholesterol screening and assessment of risk and therapy. Am.J. Cardiol. 81:26B-31B.

29. Garg, A., and Grundy, S.M. 1990. Management of dyslipidemia in NIDDM [review]. Diabetes Care. 13:153-169.

30. National Cholesterol Education Program. 2002. Third Report of the National Cholesterol Education Program (NCEP) Expert Panel on Detection, Evaluation, and Treatment of High Blood Choles- terol in Adults (Adult Treatment Panel III): final report. Circulation. 106:3143-3421.

31. Sniderman, A.D. 2002. How, when, and why to use apolipoprotein B in clinical practice. Am. J. Cardiol. 90:48i-54i.

32. Alaupovic, P. 1991. Apolipoprotein composition as the basis for classifying plasma lipoproteins. Characterization of apoA- and apoB-containing lipoprotein families. Prog. Lipid Res. 30:105-138.

33. Alaupovic, P. 1996. Significance of apolipoproteins for structure, function, and classification of plasma lipoproteins. Meth. Enzymol. 263:32-60.

34. De Lalla, O.F., Elliott, H.A., and Gofman, J.W. 1954. Ultracentrifugal studies of high-density serum lipoproteins in clinically healthy adults. Am. J. Physiol. 179:333-337.

35. Gidez, L.I., Miller, G.J., Burstein, M., Slagle, S., and Eder, H.A. 1982. Separation and quantitation of subclasses of human plasma high density lipoproteins by a simple precipitation procedure. J. Lipid Res. 23:1206-1223.

36. Asztalos, B.F., Sloop, C.H., Wong, L., and Roheim, P.S. 1993. Two-dimensional electrophoresis of plasma lipoproteins: recognition of new apo A-Icontaining subpopulations. Biochim. Biophys. Acta. 1169:291-300.

\title{
Endothelial cell culture: beginnings of modern vascular biology
}

\author{
Ralph L. Nachman ${ }^{1}$ and Eric A. Jaffe ${ }^{2}$ \\ 1Department of Medicine, Weill Medical College of Cornell University, New York, New York, USA. \\ ${ }^{2}$ Department of Medicine, Interfaith Medical Center, Brooklyn, New York, USA.
}

\begin{abstract}
Endothelial cells derived from human umbilical veins were first successfully cultured in vitro in 1973. Weibel-Palade bodies and the von Willebrand factor antigen were used as morphological, immunohistochemical, and functional markers to unequivocally identify the cells. These landmark studies helped initiate the growth of modern vascular biology.
\end{abstract}

It was a warm sunny afternoon late in the spring of 1969 when one of us (Nachman) spent an hour in the office of a renowned cell biologist discussing why his laboratory wanted to study the biology of endothelial cells. Nachman tried to convey the conviction that this had to be the key to understanding how the blood vessel wall worked. Despite his enthusiasm, the essence of the response received was: "You are probably dealing with the inner tube of a tire and, in fact, if you can grow them in culture, you will probably end up with a nondescript fibroblast. Stick to platelets and blood coagulation.” Lord Adrian Florey apparently had the same attitude, referring to

Conflict of interest: The authors have declared that no conflict of interest exists.

Citation for this article: J. Clin. Invest. 114:1037-1040 (2004). doi:10.1172/JCI200423284.

endothelial cells as "a sheet of nucleated cellophane” $(1,2)$. Fortunately, we ignored the advice $(3,4)$ as well as the literature.

\section{Figure 1}

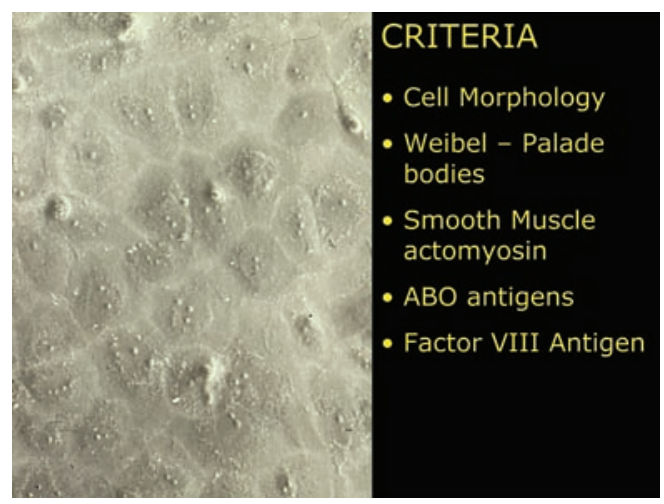

Summary slide presented at the plenary session of the $1974 \mathrm{ASCl}$ annual meeting in Atlantic City showing the first cultured endothelial cells and the criteria used to identify them.

The late 1960 s and early 1970 s were particularly exciting times to be involved in studying the biology of hemostasis. Explosive new ideas were revolutionizing the concepts of blood coagulation physiology and biochemistry $(5,6)$. At the same time, the role of the circulating platelet as the major player in primary hemostasis, leading to the arrest of bleeding, and the paradigm of thrombo-

Investigation http://www.jci.org Volume 114 Number 8 October 2004

1037 


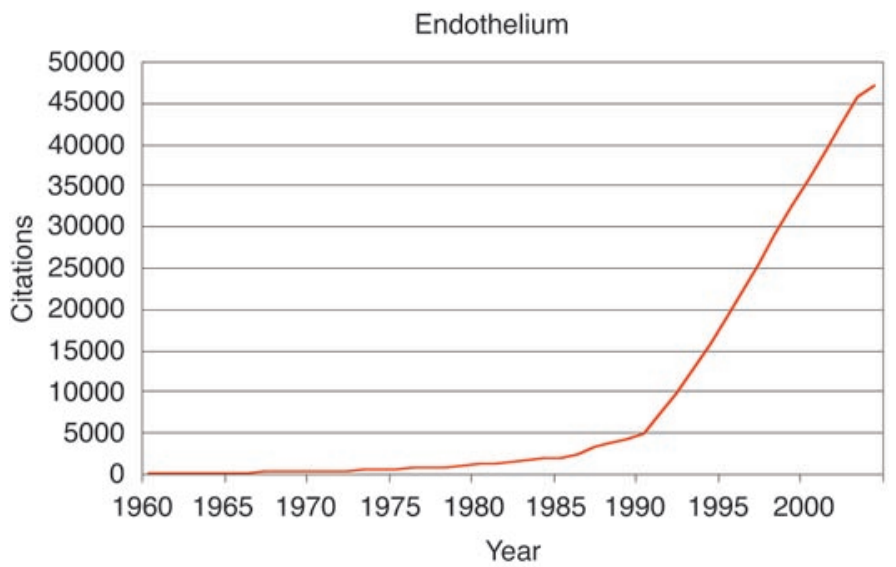

\section{Figure 2}

Cumulative citations to "endothelium" in the biomedical literature over 4 decades (according to the ISI Web of Science database). The explosive phase started in the early 1990s, coinciding with the growing interest in angiogenesis.

regulation only served to focus attention on the vessel wall and on the endothelial cell specifically. The time was clearly ripe for studying the endothelial cell directly.

In previous years, a number of attempts had been made to culture isolated vascular intimal cells. Warren Lewis (7) in 1922 was among the first to publish a study of in vitro plasma clot culture of vascular endothelium. A number of subsequent studies involved "organ" cultures using whole segments of large-animal or human arteries cultivated under various in vitro conditions without separation of the different cellular components (8). However, it was generally impossible to adequately distinguish intimal endothelial cells under those conditions. Interestingly, one study (9) suggested that endothelial cells could be derived from hematopoietic sources but transformed into fibroblasts after 4-5 generations in culture. It is probable that human aortic endothelial cells were grown successfully in culture in 1958 (10). Sheetlike polygonal monolayers were grown, but again definitive identification was not possible, and the potential importance of the work was not appreciated. Yuji Maruyama (11) was the first to report the in vitro culture of human umbilical vein endothelial cells, but these cells were not definitively identified, and it was generally felt that they were in fact fibroblasts. Other later attempts $(12,13)$ were similarly received with skepticism.

When we proposed trying to culture endothelial cells, our colleagues were rather surprised at first, since the focus and expertise of the lab was platelets and endothelial cells, and the new direction seemed to be off the beaten track. A previous fellow with experience in tissue culture had tried, unsuccessfully, to culture endothelial cells. Further, Jaffe had no experience at all in tissue culture, and neither did anyone else in the lab. These conditions seemed to Jaffe to be rather inauspicious, and as a result, there were some misgivings about spending the research year of a hematology fellowship on this project. However, we persisted, and Jaffe soon committed to the project.

To remedy a total lack of knowledge of tissue culture, Jaffe consulted Karen Artzt, then a graduate student at Cornell University. She was conversant with the ins and outs of tissue culture, and during an afternoon in her lab, she gave an introduction to practical tissue culture. As a parting present after the introduction was over, she loaned us a book on the subject, which was immediately devoured over the weekend, along with the pertinent reprints of previous work by others and the earlier fellow's unsuccessful results. By Monday, after a weekend of reading and planning, we started the experiments.

As a complete beginner at experimental work, Jaffe made a major but extremely effective misjudgment by simultaneously changing a large number of variables in the experimental procedures used in the previously published papers on this subject. Among other changes, the enzyme used to attempt to digest the endothelial cells from the interior of the umbilical vein was changed from trypsin to collagenase, and the amount of fetal calf serum used in the culture media was changed from $5 \%$ to $20 \%$. Since the previous techniques had limited success, we were in uncharted territory and could proceed as we thought best. We decided, as others had before us, to employ the umbilical vein as a source of endothelial cells, since umbilical cords were so readily available and easy to work with because their vessels were unbranched and of decent size.

Our initial attempt at isolating endothelial cells was performed on a Monday (June 28, 1971), and the isolated cells were cultured overnight. By Tuesday, it was immediately obvious that we were on the right track. We had clearly cultured what appeared to be endothelial cells - a monolayer of very flat, polygonal-shaped cells. However, since the experiment had been a preliminary run-through performed on a counter top rather than in a tissue culture laminar flow hood, we had used less-than-sterile technique, and the cultures were heavily contaminated with fungus. Over the next two days, we repeated the experiments using proper sterile technique, and by Thursday (July 1), we had obtained a sterile culture of what we believed were endothelial cells. The cells divided and multiplied in vitro in tissue culture and could be passaged a number of times, which allowed us to study their functions. Our successful multiple and simultaneous alterations in the isolation and culture conditions enabled future investigators to easily obtain pure cultures of endothelial cells for use in their studies.

However, complete acceptance of the nature of our cultured cells depended on definitively identifying them as endothelial cells. At the time, the known definitive endothelial cell markers were useful in characterizing small numbers of cells but could not be used to look at large populations of cells. While the cultured putative endothelial cells contained Weibel-Palade bodies, as determined by electron microscopy, the technique was not suitable for scanning large numbers of cells. Similarly, while we could scan large numbers of cells for $\mathrm{ABO}$ blood group antigens - whose presence was consistent with the ABO blood type of the umbilical cord donor - only $20-30 \%$ of our cultured endothelial cells expressed the antigen, which left the nature of the $\mathrm{ABO}$ antigen-negative cells in doubt.

Providently, Lee Hoyer presented work at the April 1972 FASEB conference showing that in tissue sections, endothelial cells contained antihemophilic factor antigen, now called von Willebrand factor. In his studies, vWF antigen was present in endothelial cells in all tissues tested by immunofluorescence but was not present in smooth muscle cells or in fibroblasts (14). In collaboration with 


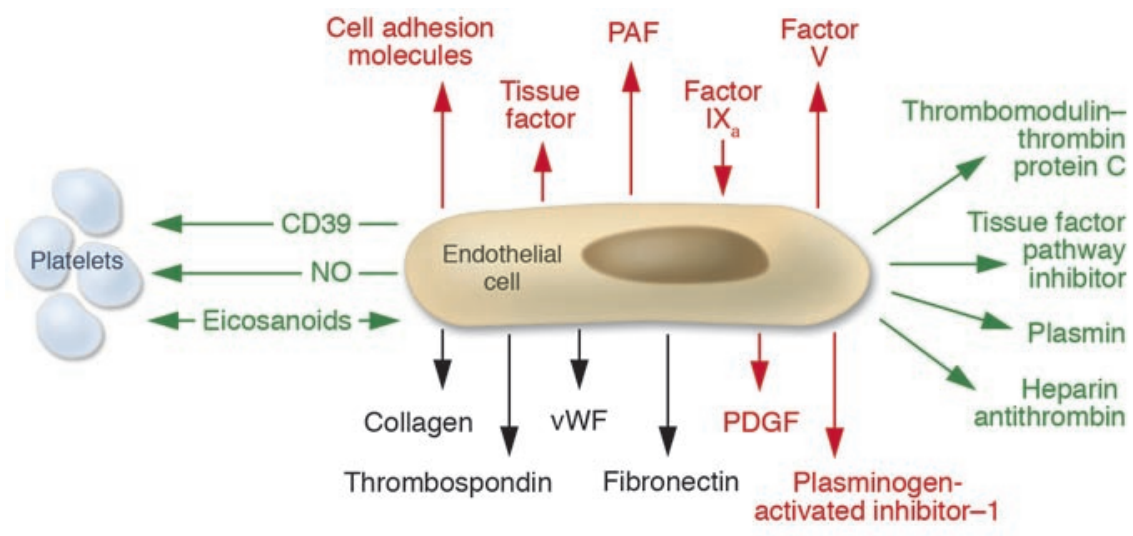

Figure 3

The endothelial cell as the maestro of thromboregulation. Non-thrombogenic functions shown in green include the thrombomodulin-thrombin protein $C$ system, tissue factor pathway inhibitor, plasmin generating system, and the heparin antithrombin system. Additionally, there are non-thrombogenic interactions with platelets through CD39, nitric oxide, and the eicosanoid pathway. Non-constitutive "activated" functions (red) on the luminal side of the cell include upregulation of cell adhesion molecules and tissue factor, factor IX $\mathrm{X}_{\mathrm{a}}$ binding, platelet activating factor release (PAF), factor $V$ synthesis, and basally: PDGF release and plasminogenactivated inhibitor-1 release. Abluminal matrix deposition of collagen, vWF, fibronectin and thrombospondin are also shown.

him, we studied the expression of vWF antigen by our cultured endothelial cells and were able to demonstrate that the cells in our culture all contained vWF, whereas vWF was absent in all cultured smooth muscle cells and fibroblasts. This observation enabled us to definitively demonstrate that our cultured cells were endothelial cells, and the details of our papers also provided other laboratories with an easy and accurate identification method. This work in two papers, one describing the isolation and culture of the cells along with electron microscopy and immunologic studies and the other describing our vWF studies, was published ad seriatim in the JCI in November $1973(3,4)$. A summary of the key findings as presented at the plenary session of the ASCI annual 1974 meeting in Atlantic City, New Jersey, is shown in Figure 1.

Our two papers and a study published a year later (15) had a catalytic effect, initiating a broad interest in the field and ushering in the development of modern vascular biology as a major focus of biomedical research. A time line illustrating the growth of citations of "endothelium" in the biomedical literature is shown in Figure 2. It is apparent that the last 15 years have witnessed a veritable explosion of scientific activity dealing with this tissue. Our clear-cut demonstration of the synthesis of vWF by endothelial cells (16) furnished the scientific community with a firm biochemical marker to identify and track these cells in various biological settings, including in vitro and in vivo conditions. In addition, an appreciation of the cellular biology of the platelet and the blood coagulation system clearly defined the endothelial cell as the maestro of thromboregulation (Figure 3). It soon became clear that a major physiologic constitutive function of normal endothelium was the maintenance of normal blood fluidity and the establishment of a steady state of non-thrombogenicity. Downregulation of platelet activation and thrombin generation constituted a major role of normal endothelium. The endothelial cell began to assume center stage in the biology of the blood vessel wall, with important clinical implications. A number of inherited primary thrombophilic states were found to be associated with abnormalities of endothelial cell-mediated anticoagulant membrane functions (Figure 3). In contrast, some pathological clinical conditions such as sepsis were found to be associated with the conversion to a non-constitutive activated endothelial state with an inflammatory thrombogenic phenotype $(17,18)$.

In the last decade, important advances in endothelial cell biology have had a major impact on our understanding of numerous pathophysiologic conditions. The activated endothelial cell in various clinical states, including inflammatory diseases and cancer, has become a major target of human therapeutics $(19,20)$. Dysfunctional endothelium appears to contribute significantly to systemic vascular disorders such as atherosclerosis
(21). Biomechanically inducible endothelial cell genes alter the endothelial cell phenotype and contribute to lesion formation and progression. Mechano-transduction at the membrane surface in response to specific fluid mechanical forces is a major variable in determining the local geography of vasculopathic disorders (22). Another local factor that clearly determines disease expression is the functional heterogeneity of different vascular beds (23). Recent studies employing gene expression profiling have shown significant endothelial cell diversity at different sites in the vascular tree (24). There are marked differences in the genotype of large vessel and microvascular endothelium. In addition, specific arterial and venous gene expression profiles have been identified. The resultant phenotypic differences characterize specific clinical disorders. For instance, the lesions typical of thrombotic thrombocytopenic purpura are not seen in the vascular beds of the liver or lung (25). Similarly, intra-abdominal thrombosis of the hepatic and portal veins are characteristic features of myeloproliferative states (26). It has become abundantly clear that the tissue microenvironment surrounding blood vessels controls endothelial cell phenotype. Recent proteomic studies have identified endothelial cell proteins restricted to specialized membrane microdomains expressed in specific tissues (27). These "molecular addresses" in solid tumors, essentially unexpressed in normal tissue, have become targets for endothelial cell-focused tissue-specific therapy (27). The therapeutic impact of the vascular biology explosion involving angiogenesis-modulating agents that interfere directly with invasive tumor growth and metastasis has already begun to influence modern chemotherapy $(28,29)$.

The relationship of endothelial cells to stem cells has received increasing attention in recent years. Bone marrow-derived endothelial cell progenitors can restore tissue vascularization after ischemic insults (30). This raises the intriguing possibility of ex vivo production of autologous endothelium for various therapeutic purposes. Endothelial cell trophic factors, yet to be fully identified, regulate neural and possibly pancreatic as well as liver stem cell proliferation and differentiation (31). This exciting new role of the endothelium as a "tissue architect" awaits future studies.

With the passing of more than 3 decades, it is interesting to speculate on why our two papers had such a revolutionary impact on the growth and development of the field of 
vascular biology. It is apparent that two key variables were crucial in focusing attention on the work: (1) easy availability of a source tissue (umbilical vein) to isolate and grow a relatively pure population of cells; and (2) identification of an easily demonstrable immunohistochemical and functional marker (vWF) to unequivocally identify the cells in question. Thus the biomedical community was able to appreciate and characterize a heretofore unrecognized and inaccessible endothelial organ, of great importance in human health and disease. Looking back at these successful experiments is gratifying, but looking ahead at the potential human therapeutic possibilities based on these discoveries is even more exciting.

Address correspondence to: Ralph L. Nachman, Department of Medicine, Weill Medical College of Cornell University, 1300 York Avenue, New York, New York 10021, USA. Phone: (212) 746-4720; Fax: (212) 746-8793; E-mail: rlnachm@mail.med.cornell.edu.

1. Florey, Lord. 1966. The endothelial cell. Br. Med. J. 2:487-490.

2. Kaiser, L., and Sparks, H.V. 1987. Endothelial cells. Not just a cellophane wrapper. Arch. Intern. Med. 147:569-573

3. Jaffe, E.A., Nachman, R.L., Becker, C.G., and Minick, C.R. 1973. Culture of human endothelial cells derived from umbilical veins: identification by morphologic and immunologic criteria. J. Clin. Invest. 52:2745-2756.

4. Jaffe, E.A., Hoyer, L.W., and Nachman, R.L. 1973.
Synthesis of antihemophilic factor antigen by cultured human endothelial cells. J. Clin. Invest. 52:2757-2764

5. Davie, E.W., and Ratnoff, O.D. 1964. Waterfall sequence for intrinsic blood clotting. Science. 145:1310-1312.

6. Macfarlane, R.G. 1964. Haematology: An enzyme cascade in the blood clotting mechanism and its function as a biologic amplifier. Nature. 20:498-499.

7. Lewis, W.H. 1922. Endothelium in tissue cultures. Am. J. Anat. 30:39-60.

8. Lazzarini, A.A. 1959. The effects of lipoid emulsions on arterial intimal cells in tissue culture in relation to atherosclerosis. Ph.D. thesis. Cornell University Medical College. New York, New York, USA.

9. Törö, E. 1937. Untersuchungen über die potenz endothelzellen bei der gefäss bildung en der gewebekultur. Archiv für Experimentelle Zellforschung besonders Gewbezüchtung. 20:156-171.

10. Ingenito, E.F. 1958. Cells of human heart and aorta grown in tissue culture. AMA Arch. Pathol. 65:355-359.

11. Maruyama, Y. 1963. The human endothelial cell tissue culture. Z. Zellforsch. Mikrosk. Anat. 60:69-79.

12. Fryer, O.G., Birnbaum, G., and Luttrell, C.N. 1966. Human endothelium in cell culture. J. Atheroscler. Res. 6:151-163.

13. Pomerat, C.M., and Slick, W.C. 1963. Isolation and growth of endothelial cells in tissue culture. Nature. 198:859-861.

14. Hoyer, L.W., de los Santos, R.P., and Hoyer, J.R. 1973. Antihemophilic factor antigen. Localization in endothelial cells by immunofluorescence microscopy. J. Clin. Invest. 52:2737-2744.

15. Gimbrone, M.A., Cotran, R.S., and Folkman, J. 1974. Human vascular endothelial cells in culture. Growth and DNA synthesis. J. Cell Biol. 60:673-684.

16. Jaffe, E.A., Hoyer, L.W., and Nachman, R.L. 1974. Synthesis of von Willebrand factor by cultured human endothelial cells. Proc. Natl. Acad. Sci. U. S. A. 71:1906-1909.

17. Stern, D.M., et al. 1991. Endothelium and regulation of coagulation. Diabetes Care. 14:160-166.
18. Stern, D.M., Kaiser, E., and Nawroth, P. 1988. Regulation of the coagulation system by vascular endothelial cells. Hemostasis. 18:202-214.

19. Bernard, G., et al. 2001. Efficacy and safety of recombinant human activated protein $\mathrm{C}$ for severe sepsis. N. Engl. J. Med. 344:699-709.

20. Schnitzer, J.E. 1998. Vascular targeting as a strategy for cancer. N. Engl. J. Med. 339:472-474.

21. Gimbrone, M.A., et al. 1997. Hemodynamics, endothelial gene expression and atherogenesis. Ann. N. Y. Acad. Sci. 811:1-10.

22. Gimbrone, M.A., et al. 1999. The critical role of mechanical forces in blood vessel development physiology and pathology. J. Vasc. Surg. 29:1104-1151.

23. Aird, W.C. 2003. Endothelial cell heterogeneity. Crit. Care Med. 31:5221-5230.

24. Chi, J.T., et al. 2003. Endothelial cell diversity revealed by global expression profiling. Proc. Natl. Acad. Sci. U. S. A. 100:10623-10628.

25. Nachman, R.L. 2001. Hypercoagulable states: challenges and opportunities. Trans. Am. Clin. Climatol. Assoc. 112:161-179.

26. Valla, D., et al. 1985. Primary myeloproliferative disorder and hepatic vein thrombosis. Ann. Intern. Med. 103:329-334.

27. Oh, P., et al. 2004. Subtractive proteomic mapping of the endothelial surface in lung and solid tumors for tissue specific therapy. Nature. 429:629-635.

28. Kudelka, A.P., Verschaegen, C.F., and Loyer, E. 1998. Complete regression of metastatic cervical cancer with the angiogenesis inhibitor TNP -470 . N. Engl. J. Med. 338:991-992.

29. Yang, J.C., et al. 2003. A randomized trial of bevacizumab; an anti vascular endothelial growth factor antibody for metastatic renal cancer. N. Engl. J. Med. 349:427-434.

30. Rafii, S., and Lyden, D. 2003. Therapeutic stem and progenitor cell transplantation for organ vascularization and regeneration. Nat. Med. 9:702-712

31. Shen, Q., et al. 2004. Endothelial cells stimulate self-renewal and expand neurogenesis of neural stem cells. Science. 304:1338-1340.

\title{
One thing leads to another
}

\author{
Jules Hirsch \\ Laboratory of Human Behavior \& Metabolism, Rockefeller University, New York, New York, USA.
}

\begin{abstract}
In 1956, the JCI published an article by Vincent Dole on a method for titrating plasma fatty acids that uncovered the importance of fatty acids as a substrate for glucose metabolism. When asked to prepare a historical perspective on this very popular paper, I paid Dole a visit and we reminisced. His answer to my question of how he came to do this work on plasma fatty acids was: "Well, one thing leads to another." Let me remind the reader of what "things" were like in 1956 and how they might have related to Dole's important contribution.
\end{abstract}

In 1954, when I began research in lipid chemistry and metabolism, overall biochemical understanding was being greatly energized

Nonstandard abbreviations used: NEFA, non-esterified fatty acid.

Conflict of interest: The author has declared that no conflict of interest exists.

Citation for this article: J. Clin. Invest. 114:1040-1043 (2004). doi:10.1172/JCI200422993. and expanded by the availability of isotopically labeled compounds and new analytic techniques, but lipid research was developing more slowly. It was appreciated that fats were the largest source of stored energy in the body and were also the major constituents of membranes, yet the then-current, 900-page biochemistry text of Fruton and Simmonds devoted only 25 pages to fats, phospholipids, and fatty acids (1). The real excitement was elsewhere, in learning about the structure and conformation of proteins and coming to grips with the molecular mechanisms of enzymatic control in living systems. In intermediary metabolism, the central players were the carbohydrates; updates of the latest findings could be found in large, colorful metabolic maps on doors or walls in the cramped office space of academic researchers.

Lipid research lagged because the separation of the various chemical classes of lipids required for many experiments was extremely tedious, and the characterization of molecular structures within each class was time consuming and often not reproducible. Even the name was uncertain - some investigators called them "lipids," and others, "lipides." JAMA and Lancet insisted that "lipids" 